\title{
Manajemen Risiko, Internal Kontrol, Tata Kelola Perusahaan dan Kinerja Keuangan BUMN dengan Maturity Level Departemen Audit Internal sebagai Pemoderasi
}

\author{
Monang Nixon Haposan Tampubolon \\ Universitas Pancasila , Jakarta, Indonesia
}

\section{INFO ARTIKEL \\ JEL Classification : G32, H83}

\section{Keywords :}

internal audit, finacial performance, internal control, risk management

\begin{abstract}
Internal Auditor are considered as significant Management tool in ensuring the proper implementation of company business process to achieve company goals, especially after the financial cases of some big companies. In accordance with stock market regulation and Goverment regulation (GR and BUMN Laws), the State Own Enterprises (BUMN) in Indonesia must have Internal Audit Department. The various size and maturity (organization size and profesionality) of Internal Audit Department raise very basic question about their capability. The certification of Maturity Level of Internal Audit Department considered as the solution to prove the capability of Internal Audit Department in helping Organization to achieve company objectives, e.g., Financial Performance. This article trying to explore and deliver research idea about the relation of Maturity Level of Internal Audit Department with Company's management tools consist of Internal Control, Risk Management and Governance in relation to the improvement of Financial Performance in State Own Enterprices
\end{abstract}

\begin{abstract}
ABSTRAK
Auditor Internal sebagai alat Management dalam mengawasi jalannya proses bisnis perusahaan dalam usaha pencapaian tujuan perusahaan dirasa sangat penting, terutama sejak terjadinya sejumlah kasus keuangan dari beberapa perusahaan besar. Sesuai peraturan Pasar Modal dan Pemerintah (PP dan Undang-undang BUMN), perusahaan BUMN di Indonesia diwajibkan untuk memiliki Departemen Audit Internal. Keberagamanan ukuran dan tingkat kemapanan (besar organisasi dan keahlian) dari Departemen Audit Internal di BUMN menimbulkan pertanyaan mendasar terkait keandalannya. Sertifikasi Maturity Level dari Departemen Audit Internal dipandang sebagai solusi untuk meyakinkan tingkat keandalan Auditor Internal didalam mensuksekan pencapaian tujuan perusahaan yang salah satunya diukur dengan kinerja keuangan. Tulisan ini ingin menguraikan dan memberikan ide penelitian hubungan Maturity Level Departemen Audit Internal dengan alat management perusahaan yang terdiri dari Pengawasan Internal, Manajemen Risiko dan Tata kelola yang ada di Perusahaan dalam rangka peningkatan Kinerja Keuangan Perusahaan BUMN.
\end{abstract}




\section{Pendahuluan}

\section{Latar Belakang Penelitian}

Auditor Internal sebagai alat Management didalam mengawasi jalannya proses bisnis perusahaan dalam usaha pencapaian tujuan perusahaan dirasa sangat penting, terutama sejak terjadinya sejumlah kasus keuangan dari beberapa perusahaan besar. The Institute-ofInternal Auditor sebagai wadah organisasi Auditor Internal tingkat dunia membuat definisi Internal Auditing dimana didalamnya memuat tugas dari internal audit. Definisi tersebut juga secara tegas menyatakan bahwa tugas utama Auditor Internal adalah untuk mengevaluasi dan memberikan rekomendasi perbaikan terkait keefektifan proses Managemen Risiko (risk management), Kontrol (control) dan Tatakelola (governance). Definisi tersebut juga jelas menegaskan tujuan akhir dari fungsi Audit Internal yaitu membantu operasi perusahaan dalam mencapai tujuan perusahaan. Profesi Auditor Internal sebagai alat Management didalam mengawasi jalannya proses bisnis perusahaan dirasa sangat penting, terutama sejak terjadinya sejumlah kasus keuangan dari beberapa perusahaan besar yang mendorong Dewan Kongres dan Senat di Amerika untuk mengeluarkan peraturan Sarbaness-Oxley-Act. pada tahun 2002. Sarbanes-Oxley (Sarbanes Oxley Act of 2002, Public Company Accounting Reform and Investor Protection Act. of 2002) atau biasa disingkat SOx adalah hukum pemerintah pusat Amerika Serikat yang dikeluarkan 30 Juli 2002 sebagai tanggapan atas sejumlah kasus akuntansi perusahaan dimana anatara lain melibatkan Enron, Tyco International, Adelphia, Peregrine Systems, WorldCom (MCI), AOL Time Warner, Aura Systems, Citigroup, Computer Associates International, CMS Energy, Global Crossing, HealthSouth, Questz Communication, Safety-Kleen dan Xerox, yang juga melibatkan beberapa Akuntan Publik seperti: Arthur Andersen, KPMG dan PWC. Kasus-kasus kerugian bernilai bilyunan dolar akibat harga saham perusahaan-perusahaan yang terpengaruh ini turun drastis mengguncang kepercayaan masyarakat terhadap pasar saham. Undangundang Amerika Serikat yang diprakarsai oleh
Senator Paul Sarbanes (Maryland) dan Representative Michael-Oxley (Ohio) serta disahkan oleh Presiden George.W.Bush. Perundang-undangan ini menetapkan aturan yang lebih baik bagi semua perusahaan publik serta Kantor akuntan publik. Sarbox juga menuntut Securities-and-ExchangeCommission (SEC) turut aturan baru ini. Dengan diterbitkannya Sox's dan ditambah dengan beberapa aturan pelaksanaan, diharapkan dapat meningkatkan akuntabilitas perusahaan, transparansi laporan keuangan, serta memperkecil perusahaan atau organisasi untuk melakukan kecurangan atau fraud, serta memberikan keutamaan pada tercipatanya corporate-governance yang baik.

Sarbox menetapkan Public-CompanyAccounting-Oversight-Board (PCAOB), untuk bertugas mengawasi, mengatur, memeriksa, serta memberikan arahan kepada para kantor akuntan agar bertindak sesuai dengan mandat auditor perusahaan publik. Sarbox juga mengatur kebebasan auditor, tata kelola perusahaan, penilaian pengendalian internal, serta pengungkapan laporan keuangan. Dengan kata lain, Sarbaness-Oxley dibuat untuk kepentingan investor dengan menciptakan good-corporate-governance, full-disclosure, dan accountability. SOA khususnya section 404 menuntut adanya laporan manajemen tahunan (annual management report) atas pengendalian intern atas proses pelaporan keuangan. Laporan manajemen tersebut merupakan subjek yang akan diaudit. Dalam seksi SOX Act. seksi-404 dimuat aturan yang berisi kewajiban bagi manajemen perusahaan untuk menilai pengendalian intern (Internal Control) yang sudah dilaksanakan atas proses penyusunan laporan keuangannya; Perusahaan setiap tahun diwajibkan untuk melakukan evaluasi pengendalian internal atas laporan keuangan dan pada akhir tahun Manajemen harus memberikan opini tentang efektifitas dari pengendalian internalnya. Pihak yang bertanggungjawab untuk melakukan evaluasi atas pengendalian internal adalah bagian Audit Internal. Akuntan publik yang dipakai perusahaan dalam memeriksa laporan tahunan diwajibkan untuk melaporkan hasil evaluasi 
mereka atas pengendalian internal yang ada. Seksi 404 secara khusus memberikan perhatian kepada internal kontrol perusahaan atas laporan keuangannya. Dalam mengevaluasi internal kontrol, manajemen melalui departemen audit perlu mengacu pada kerangka COSO (Committee of Sponsoring Organization of the Tradeway Commission). Pada SOXs-Act. 2002 hal yang terkait Internal Control ditekankan dalam seksi 302 yang mensyaratkan perlunya dokumen penjelasan manajemen terkait sistem pengawasan yang ada pada perusahaan. Pihak yang harus bertanggungjawab terhadap pengungkapan pengawasan perusahaan yaitu direktur utama dan direktur keuangan.

Audit internal selama bertahun-tahun telah mengalami perubahan dramatis yang mengarah pada lingkup yang diperluas yang memungkinkan audit internal untuk memberikan kontribusi bagi organisasi. Belajar dari sisi postif penerapan Sarbaness Oxley Act. 2002 bagi semua perusahaan Amerika di bursa saham New York (NYSE) dan aktivitas bisnisnya diseluruh dunia, muncul beberapa negara yang mempraktekan inti dari Sarbaness Oxley Act. tersebut salah satunya termasuk Indonesia.

Dalam Undang-undang BUMN no. 19/2003 dan PP 45/2005 perihal "Pendirian, Pengurusan, Pengawasan dan Pembubaran BUMN", dijelaskan tentang eksistensi, tugas dan tanggung jawab, serta pelaporan Satuan Pengawas Internal (SPI).

SPI (Satuan Pengawas Internal) bertugas:

(a) Membantu Direktur-Utama dalam melaksanakan pemeriksaan-operasional dan keuangan BUMN, menilaipengendalian, pengelolaan-dan pelaksanaannya pada BUMN serta memberikan saran-saran perbaikannya;

(b) Memberikan keterangan tentang hasil pemeriksaan kepada Direktur Utama; dan

(c) Memonitor tindak lanjut atas hasil pemeriksaan yang telah dilaporkan.

Apabila diminta secara tertulis oleh Komisaris/Dewan-Pengawas, Direksi wajib memberikan informasi hasil pemeriksaan atau, hasil pelaksanaan tugas SPI. (UU BUMN no. 19, 2003).

\section{Telaah Teori dan Pengembangan Hipotesis}

Landasan teori dari penelitian ini, yaitu teori organisasi (Organization Theory) dan teori keagenan (Agency Theory). Teori Organisasi melandasi penelitian ini karena menunjukkan hakikat perusahaan sebagai sebuah organisasi yang kompleks dan harus memiliki mekanisme yang terstruktur dalam mencapaian misi dan visi organisasi dengan tetap memperhatikan kepentingan tiap individu yang terlibat. Sedangkan Teori Keagenan menunjukkan hubungan antara perusahaan dengan penyedia modal. Kedua teori tersebut memiliki penjelasan tentang pengendalian dan kinerja perusahaan yang menjadi isu utama dalam penelitian ini.

\section{Teori Organisasi}

Teori organisasi dilandasi filosofi bahwa manusia perlu bekerja sama untuk memenuhi kebutuhan oleh karena itu, dalam sebuah organisasi diperlukan pengendalian perilaku untuk mencapai tujuan bersama. Kata kunci pada teori ini adalah kerjasama atau koordinasi. Koordinasi tersebut merupakan cara mencapai tujuan bersama supaya efektif dan efisien. Untuk itu, organisasi harus memiliki mekanisme untuk mencegah dan menghindari penghalang tujuan. Mekanisme kerjasama pada sebuah organisasi harus dilandasi pemahaman oleh tiap individu akan pentingnya tujuan bersama. Namun penetapan tujuan tersebut diwarnai perdebatan terkait kepentingan siapa atau pihak mana yang diprioritaskan. Perdebatan tersebut juga berdampak pada konsep mekanisme pengendalian organisasi karena pihak-pihak yang kepentingannya terakomodasi dalam tujuan organisasi, memerlukan mekanisme pengendalian yang menjamin tercapainya tujuan tersebut. Teori organisasi mengalami perkembangan hingga muncul dua paradigma mengenai organisasi, yaitu teori organisasi modern dan teori organisasi neo-modern. Pada teori organisasi modern, supaya organisasi efektif dan efisien dalam rangka mencapai tujuannya, maka organisasi harus dirancang dengan struktur yang jelas disertai dengan deskripsi tugas yang sistematis, dengan memperhatikan kejelasan otoritas dan pertanggungjawaban. Berdasarkan paradigma dalam organisasi modern tersebut, jika 
dihubungkan dengan teori mengenai hubungan stakeholders' dari sebuah organisasi, maka dapat dirujuk teori yang terkait, yaitu teori keagenan. Teori keagenan menjelaskan mekanisme pengendalian organisasi dengan menggunakan paradigm organisasi modern. Jika dikaitkan dengan isu Manajemen Risiko, Pengendalian Internal dan Tata kelola Perusahaan, maka teori keagenan lebih relevan.

\section{Teori Keagenan}

Teori Agensi didasari pada persoalan agensi yang terjadi disaat pengelolaan perusahaan terpisah dari kepemilikannya. Perusahaan adalah suatu mekanisme yang memberikan peluang pada semua partisipan untuk berpartisipasi dalam hal modal, keahlian dan tenaga kerja dengan tujuan memaksimalkan keuntungan jangka panjang. Pemilik (principal) merupakan partisipanpartisipan yang berpartisipasi pada modal. Pengelola perusahaan (agen) merupakan partisipan-partisipan yang berpartisipasi dengan bekal keahlian dan tenaga-kerja. Keberadaan kedua partisipan ini menimbulkan persoalan pada mekanisme yang harus dibuat untuk menyesuaikan perbedaan kepentingan pada kedua partisipan tersebut. Teori keagenan dikhususkan untuk menangani persoalan yang terjadi di dalam hubungan keagenan.

Pertama, permasalahan keagenan muncul ketika (a) kepentingan kedua partisipan (principal dan agen) berlawanan dan (b) principal sangat sulit melakukan verifikasi hal-hal yang benar-benar dilakukan agen. Hal ini dikarenakan prinsipal tidak bisa memverifikasi apakah agen tersebut melaksankan semuanya secara tepat.

Kedua, permasalahan dalam pembagian resiko yang muncul ketika kedua partisipan (prinsipal dan agen) mempunyai sikap yang berlawanan terhadap resiko. Oleh karenanya diciptakan kontrak yang dapat menyelaraskan kepentingan principal dan agen. Kontrak antara investor dengan manajer merupakan kontrak yang bisa menjelaskan spesifikasi yang wajib dilakukan manajemen dalam mengelola dana tiap investor, dan spesifikasi terkait pembagian hasil antara manajemen dan investor. Secara ideal, investor serta manajer menandatangani kontrak secara lengkap, terdapat spesifikasi yang tepat tentang apa saja yang wajib dikerjakan manajemen dalam setiap kemungkinan yang dapat terjadi, dan bagaimana pengalokasian keuntungan perusahaan. Namun demikian, kontrak yang lengkap susah untuk di wujudkan, hal ini dikarenakan adanya faktor kontinjensi yang sulit untuk diramalkan sebelumnya. Oleh karena itu manajer harus memiliki hak pengendalian residual (residual control right) yang diberikan oleh investor, dimana manajer dapat membuat keputusan pada kondisikondisi yang tidak terdapat di dalam kontrak. Hak yang dimiliki oleh manajer ini kemungkinan bisa disalah gunakan sehingga memunculkan permasalahan keagenan. Hak pengendali residual juga dimiliki oleh pemilik modal untuk dapat memutuskan hal yang tidak terduga, tetapi pemilik modal tidak memiliki kemampuan untuk mengetahuihal hal yang wajib dilakukan sehingga pengalokasian hak pengendalian residual menjadi tidak efektif.

Guna mengatasi masalah keagenan, maka dirasa perlu untuk membuat strategi desain pengendalian untuk menjamin tercapainya tujuan organisasi yang memberikan hasil maksimal bagi agen dan principal. Strategi tersebut dengan menggunakan perangkat yang dirancang berupa proses Manajemen Risiko, Pengendalian Internal, Tata Kelola Perusahaan dan pembentukan fungsi Audit Internal, dengan pertimbangan cost dan benefit.

\section{Maturity Level Department Internal Audit}

Auditor Internal berfungsi untuk membantu manajemen dengan mengevaluasi dan memberikan rekomendasi perbaikan proses Manajemen Risiko, Pengendalian Internal, dan Tata pengelolaan Perusahaan. Auditor internal berfungsi untuk mendukung manajemen dalam hal, yakni;

1. Mengawasi kegiatan dari manajemen puncak yang tidak dapat dilakukan oleh mereka sendiri.

2. Mengidentifikasi dan menekan kemungkinan risiko semaksimal mungkin. Semua organisasi melakukan pendekatan holistic yang mencangkup setiap resiko di perusahaan, yang berasal dari hukum, politik dan pembuat peraturan, hubungan dengan pemegang saham, dan pengaruh 
persaingan untuk menetapkan manajemen resiko.

3. Memverifikasi laporan kepada manajemen puncak. Para manajemen membuat suatu keputusan berlandaskan laporan yang dibuat auditor-internal.

4. Melindungi manajemen dalam bidang teknis. Auditor internal wajib mengetahui dari mana data berasal, bagaimana memprosesnya, dan cara pengaman datadata perusahaan.

5. Meninjau kegiatan perusahan di masa lalu dan masa depan untuk membantu proses keputusan.

6. Membantu manajer membuat perencanaan, pengorganisasi, pengarahan dan pengendalian masalah.

7. Dengan adanya peraturan yang diterbitkan oleh SEC (di Amerika) dan Bapepam (di Indonesia) yang mengharuskan perusahaan go-public dan BUMN untuk memiliki fungsi Internal Audit sehingga perusahaan go-public perlu mengalokasikan sumber dana dan tenaga guna membentuk Departemen Audit Internal agar patuh pada peraturan yang berlaku. Sampai saat ini kami belum menemukan ada aturan mengenai seberapa besar ukuran Departemen Audit Internal yang harus dibentuk dan seberapa luas cakupan pekerjaannya, sehingga saat ini terdapat keragaman tingkat kemapanan (besar organisasi dan keahlian) dari Departemen Audit Internal. Untuk mengukur tingkat kemapanan suatu Departemen Audit Internal telah dikeluarkan sebuah acuan yang dikenal dengan IACM (Internal-Audit-CapabilityModel) oleh IIA (The Institute of Internal Auditor) yang merupakan satu-satunya lembaga auditor internal yang diakui dunia. Dalam acuan tersebut ada 5 tingkatan kemapanan Departemen Audit Internal, dimana untuk masing-masing tingkatan ditetapkan kriteria-kriteria yang harus dipenuhi sebagaimana yang terdapat pada IACM Matrix.

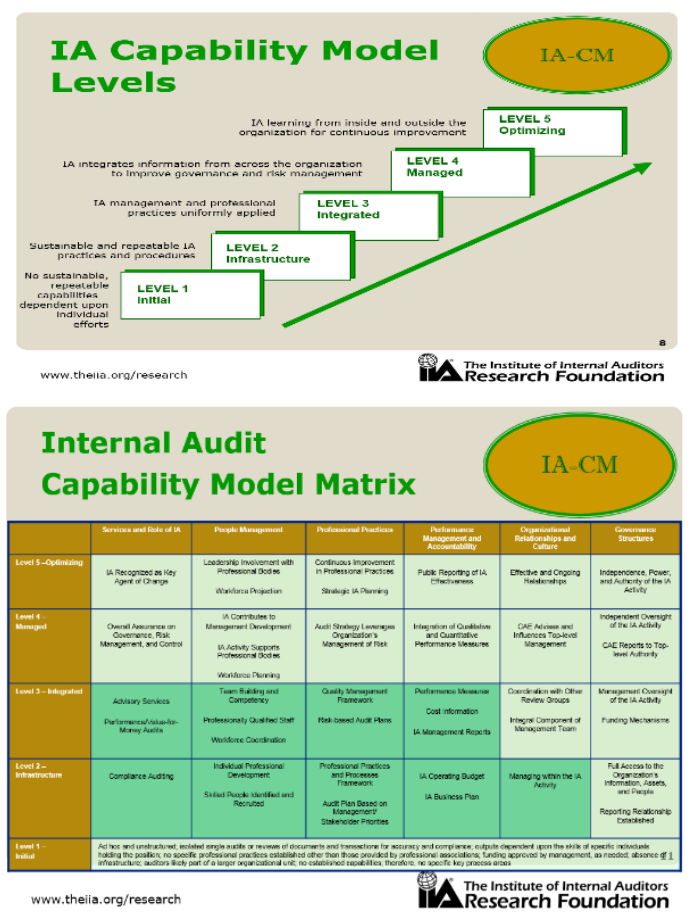

Gambar : IA Capability Model Levels dan Matrik

Pada tanggal 26 Maret 2018 di dalam forum OECD Auditor Alliance Launch Meeting, Kepala BPKP Indonesia Bapak Dr. Ardan Ardiperdana, menyampaikan bahwa tingkat kemapanan Departemen Audit Internal untuk sektor publik pada tahun 2014 dan 2017 adalah sebagai berikut (lihat Tabel; 1);

Tabel -1

Data Pencapaian tingkat kemapanan Departemen Audit Internal di Sektor Publik

\begin{tabular}{|l|l|r|r|r|r|}
\hline \multirow{2}{*}{ No. } & \multirow{2}{*}{ Level } & \multicolumn{2}{|c|}{2014} & \multicolumn{2}{c|}{2017} \\
\cline { 3 - 7 } & & Num & \multicolumn{1}{c|}{$\%$} & \multicolumn{1}{c|}{ Num } & \multicolumn{1}{c|}{$\%$} \\
\hline 1 & Level 3 & 1 & 0.2 & 106 & 16.7 \\
\hline 2 & Level 2 & 71 & 11.4 & 365 & 58.4 \\
\hline 3 & Level 1 & 385 & 61.7 & 155 & 24.7 \\
\hline
\end{tabular}

Dari tabel tersebut dapat kita lihat data usaha-usaha peningkatan tingkat kemapanan (Maturity Level) dari Departemen Audit Internal pada tahun 2014-2017 di BUMN Indonesia, dimana dari table diatas diketahui pada tahun 2014 jumlah BUMN yang telah mencapai level 3 hanya 1 Departemen Audit Internal BUMN tetapi pada tahun 2017 telah ada 106 Departemen Audit Internal BUMN. Untuk sektor publik capaian tertinggi baru mencapai Level 3 - Integrated, artinya Departemen Audit Internal yang ada di BUMN baru sebanyak 106 (16,7\%) yang telah menerapkan standar professional dan telah 
sanggup memberikan jasa konsultasi dan pemeriksaan dari kinerja Perusahaan.

\section{Manajemen Risiko (Risk Management)}

Manajemen Risiko digunakan oleh setiap praktisi untuk menanggapi berbagai macam Risiko. Secara umum ada dua macam tindakan yang dilakukan oleh responden Manajemen Risiko yaitu pertama "mencegah" dan kedua "memperbaiki". Pada tahap awal konstruksi, tindakan penncegahan digunakan untuk "mengurangi", "menghindari", atau "memindahkan" risiko. Sedangkan untuk tindakan memperbaiki berupa kegiatan untuk mengurangi efek-efek pada saat Risiko terjadi atau pada saat Risiko harus diambil. Menurut Darmawi, (2005) Keuntungan manajemen risiko yang diperoleh perusahaan terbagi dalam lima kategori utama;

a. Manajemen risiko bisa "menghindari perusahaan dari kegagalan".

b. Manajemen risiko dapat "membantu secara langsung kenaikan laba".

c. Manajemen risiko bisa "memberikan laba secara tidak langsung".

d. Adanya perlindungan terhadap risiko dasar yang merupakan harta non material sehingga bisa memberikan ketenangan pikiran bagi manajer.

e. Manajemen risiko melindungi perusahaan dari risiko dasar, sehingga para kreditur pelanggan dan pemasok menyukainya yang berakibat secara tidak langsung meningkatkan Public Image.

Manajemen Risiko merupakan cara sistematis untuk melihat suatu Risiko serta secara tepat menentukan penanganan Risiko tersebut. Manajemen Risiko adalah suatu sarana dalam pengidentifikasian sumber dari Risiko serta ketidakpastian, mengestimasi akibat yang ditimbulkan, dan mengembangkan respon untuk menghadapi Risiko. Terdapat 3 tahapan utama dalam pendekatan sistematis terkait manajemen risiko, yaitu:

\section{Identifikasi Risiko}

\section{Analisa dan evaluasi Risiko}

3. Respon atau tanggapan untuk mengendalikan Risiko tersebut.

Dalam mengidentifikasi menganalisa dan mengevaluasi risiko maka risiko yang akan dihadapi perusahaan dapat di klasifikasikan kedalam:

a) Risiko operasional merupakan risiko yang muncul dikarenakan sistem internal yang berlaku tidak berjalan sebagaimana mestinya, kesalahan dari manusia, atau kegagalan dari sistem. Sumber risiko operasional paling tinggi dapat bersumber dari kegiatan operasional dan jasa-jasa, akuntansi, sistem teknologi dari informasi, sistem informasi dari manajemen atau juga sistem pengelolaan dari sumber daya manusia.

b) Risiko eksternal merupakan Risiko yang muncul dari faktor lingkungan eksternal, dimana lingkungan eksternal bisa memunculkan kondisi kondusif bagi bencana yang dapat menimbulkan kerugian. Kerugian adalah suatu penyimpangan yang tidak diharapkan. Ada beberapa sumber penyebab kerugian dan juga risiko yang dapat diklasifikasikan sebagai sebuah risiko sosial, risiko fisik, dan juga risiko ekonomi. Menentukan sumber risiko merupakan hal yang sangat penting karena menentukan bagaimana cara penanganannya.

c) Risiko Finansial bagi investor adalah risiko akibat dari ketidakmampuan emiten saham dan obligasi dalam memenuhi kewajiban pembayaran deviden dan pokok pinjaman.

d) Risiko strategic merupakan risiko atas keadaan yang tidak terduga. Hal ini dapat mengurangi kemampuan setiap manajer dalam mengimplementasikan strateginya dengan signifikan.

\section{Proses Manajemen Risiko}

Pemahaman manajemen Risiko mengizinkan pihak manajemen untuk terlibat secara efektif pada saat menghadapi ketidakpastian risiko dan peluang yang berhubungan serta meningkatkan kemampuan suatu organisasi untuk menciptakan nilai tambah. Pembagian proses manajemen risiko berdasar COSO dibagi ke atas 8 tahap:

1. Internal-environment (Lingkunganinternal) Tahapan ini berkaitan dengan lingkungan dimana perusahaan berada dan beroperasi. Cakupannya adalah kultur manajemen terkait risiko, integritas, perspektif terhadap risiko, penerimaan 
terhadap risiko, nilai moral, struktur organisasi, dan juga pendelegasian wewenang.

2. Objective-setting (Penentuan-tujuan) Manajemen harus membuat tujuan organisasi agar dapat mengidentifikasi,meng-akses, dan mengelola suatu risiko. Objective dapat diklasifikasikan menjadi suatu strategicobjective dan activity-objective. Strategic objective di perusahaan terkait pencapaian dan kinerja dari suatu instansi dalam jangka menengah ataupun panjang, serta merupakan sebuah implementasi dari visi dan misi instansi tersebut.

3. Activity objective bisa dibagi menjadi 3 kategori, yaitu (1) operations objectives (2) reporting objective dan (3) compliance objectives. Sumber daya manusia (SDM) suatu organisasi harus dilibatkan serta mengerti risiko yang akan dihadapi. Keterlibatan tersebut berkaitan dengan anggapan semua pejabat / pegawai merupakan pemilik dari risiko. Demikian pula, dalam penentuan tujuan suatu organisasi, dapat ditentukan juga risk appetite and risk tolerance (variasi dari tujuan yang bisa diterima).

4. Risk tolerance merupakan variasi dalam pencapaian tujuan perusahaan yang bisa diterima oleh manajemen.

5. Event-identification (Identifikasi-risiko) Pada tahap ini dilakukan identifikasi kejadian yang berpotensi terjadi di internal maupun eksternal perusahaan yang dapat mempengaruhi strategi ataupun menghambat tercapainya tujuan organisasi. Terdapat 4 model pada pengidentifikasian suatu risiko, yaitu (1) Exposure-analysis; (2) Environmental analysis; (3) Threat scenario; (4) Brainstorming questions.

6. Risk assessment (Penilaian risiko). Tahapan ini dapat memberikan informasi sampai seberapa besar akibat dari events (kejadian atau keadaan) bisa mengganggu pencapaian visi dan misi perusahaan. Dampak suatu akibat bisa ketahui melalui inherent dan juga residual risk, serta dianalisis dalam dua perspektif: likelihood (kecenderungan atau peluang) dan impact / consequence (besaran akibat suatu risiko). Besarnya risiko dalam setiap kegiatan aktivitas organisasi adalah perkalian likelihood dan consequence. Aktivitas yang harus dicermati adalah events relationships yaitu hubungan antar kejadian. Events secara individu kemungkinan memiliki risiko kecil. Namun, bila digabungkan dapat menjadi signifikan. Karenanya, risiko yang dapat mempengaruhi business-units perlu untuk dikelompokkan ke dalam common-eventcategories, dan dinilai secara aggregate.

7. Risk-response (penanganan risiko) Pada tahapan ini organisasi harus bisa menentukan sikap berdasarkan hasil penilaian risiko. Risk-response dari suatu organisasi terdiri dari: (1) avoidance, yaitu kegiatan aktivitas yang berisiko atau pelayanan yang ber-risiko dihentikan; (2) reduction, yaitu pengambilan langkah untuk mengurangi peluang munculnya atau dampak risiko; (3) sharing, yaitu mengalihkan atau menanggung sebagian dengan pihak lain; (4) acceptance, yaitu menerima risiko yang akan terjadi (umumnya risiko kecil), dan tidak melakukan upaya khusus lainnya. Dalam memilih sikap, perlu untuk dipertimbangkan faktor-faktor dari pengaruh tiap sikap terhadap risk likelihood dan impact, sikap/response optimal yang dapat bersinergi dengan pemenuhan risk appetite and tolerances, analis cost versus benefits, dan juga kemungkinan adanya opportunities yang bisa timbul dari setiap tindakan risk response.

8. Control Activities (Aktifitas Pengendalian). Agar Risk response dapat dilaksanakan secara tepat, diperlukan komponen aktifitas pengendalian dalam penyusunan kebijakan-dan-prosedur. Aktifitas pengendalian memerlukan suatu lingkungan-pengendalian: (1) integritas dan juga nilai etika; (2) kompetensi; (3) kebijakan-dan-juga-praktik-praktik SDM; (4) budaya-organisasi; (5) filosofi dan juga gaya kepemimpinan manajemen; (6) struktur organisasi; dan (7) wewenang serta tanggung jawab. Dengan memahami arti dari lingkungan pengendalian, maka dapat ditetapkan jenis dan juga aktifitas pengendalian. Beberapa jenis pengendalian 
adalah; preventive, detective, corrective, dan directive. Sedangkan aktifitas pengendalian dapat berupa: (1) pembuatan kebijakan dan prosedur; (2) pengamanan kekayaan organisasi; (3) delegasi wewenang dan pemisahan fungsi; dan (4) supervisi atasan. Aktifitas pengendalian sebaiknya diintegrasi dengan manajemen risiko sehingga alokasi sumber-daya yang dimiliki organisasi-bisa-menjadi optimal.

\section{Pengendalian Internal (Internal Control)}

Suatu susunan pengendalian internal/kontrol internal (pengendalian administrative dan pengendalian akuntansi) terdiri dari kebijakan-kebijakan-dan-prosedurprosedur yang dibuat untuk memberikan kepastian secara wajar bahwa tujuan perusahaan secara khusus akan-dicapai. (SAS no. 55).

Komponen pengendalian internal mengacu pada pedoman COSO adalah:

1. Lingkungan pengendalian (control environment). Faktor-faktornya mencakup; filosofi manajemen, integritas, nilai etis, dan kompetensi, gaya operasi, otorisasi dan delegasi.

2. Penaksiran risiko (risk-assessment). Berupa mekanisme yang ditetapkan untuk indentifikasi, analisisa, dan mengelola risiko terkait aktifitas perusahaan.

3. Aktivitas pengendalian (control activities). Pelaksanaan dari kebijakan maupun prosedur yang telah ditetapkan untuk memastikan tujuan Perusahaan tercapai.

4. Informasi dan komunikasi. Merupakan suatu sistem yang mengatur orang atau entitas, memperoleh atau menukar informasi yang diperlukan dalam melaksanakan, mengelola, dan mengendalikan operasinya.

5. Pemantauan (monitoring). Kehandalan sistem pengendalian internal yang ada perlu dimonitor, untuk menilai mutu kinerja-sistem sepanjang-waktu. Ini dilakukan melalui pemantauan yang terusmenerus, evaluasi-yang-terpisah atau kombinasi-dari keduanya.

\section{Tata-Kelola Perusahaan (Good-Corporate Governance)}

Isu tentang GCG mulai menjadi fokus perhatian sejak-terjadinya berbagai kasus keuangan seperti kasus Enron dan WorldCom di Amerika, Marconi di Inggris dan Royal Ahold di Belanda yang mengindikasikan lemahnya corporate-governance, Investor institusional mulai menyadari perlunya mengevaluasi peran GCG untuk kebijakan. GCG (Good-Corporate Governance) adalah seperangkat sistem yang mengatur dan mengendalikan perusahaan untuk menciptakan-nilai-tambah bagi stakeholder. GCG memacu tersedianya pola manajemen yang profesional, transparan, bersih dan berkelanjutan. Pedoman Umum Good Corporate Governance Indonesia tahun 2006 oleh KNKG (Komite Nasional Kebijakan Governance) menyebut lima asas GCG yaitu; 1) transparansi, 2) akuntabilitas, 3) responsibilitas, 4) independensi serta 5) kewajaran dan kesetaraan. Ada dua prinsip utama dalam GCG. Pertama, terkait hak pemegang saham dalam memperoleh informasi yang akurat dan tepat waktu. Kedua, perihal itikad perusahaan dalam pengungkapan (disclosure) secara-akurat, tepat-waktu dan transparan terhadap informasi kinerja perusahaan, kepemilikan dan stakeholder.

Dengan Corporate governance para manajer memiliki pedoman dalam mengelola perusahaan secara best practice. Pengelola perusahaan diharap dapat mengambil kebijakan/keputusan keuangan yang dapat menguntungkan semua pihak (stakeholder). Manajer juga diharap bekerja secara efisien sehingga dapat menurunkan biaya dan meminimalkan risiko. Usaha tersebut diharapkan menghasilkan tingkat keuntungan yang tinggi sehingga memperoleh return sesuai dengan harapan investor, dan saham perusahaan akan diminati oleh investor. Hal ini akan meningkatkan nilai perusahaan.

Perspektif hubungan keagenan (agency theory) merupakan dasar memahami corporate governance. Konsep corporategovernance timbul sebagai upaya mengontrol perilaku manajemen yang cenderung mementingkan diri sendiri karena memiliki hak pengendali residual (residual control right). Pelaksanaan GCG di dalam perusahaan 
diharapkan mampu menghindari adanya praktek tidak terpuji yang dilakukan direksi maupun pihak-pihak lain yang punya hubungan atau kepentingan dalam perusahaan.

Dampak penerapan good corporate governance selain menghilangkan $\mathrm{KKN}$ dan menciptakan iklim berusaha yang sehat juga untuk meningkatkan kepercayaan para penanam modal dan kreditor. Dimata investor penerapan corporate governance yang baik akan menarik dan memberi kesan positif terhadap kinerja perusahaan dan nilai perusahaan.

\section{Kinerja Keuangan BUMN}

BUMN (Badan Usaha Milik Negara) merupakan perusahaan milik pemerintah yang keberadaannya dalam sistem ekonomi Indonesia masih diperlukan. BUMN selain menjalankan fungsinya sebagai sumber dana bagi pemerintah melalui pungutan pajak dan dividen, juga dibebani fungsi sebagai agentof-development (UU no.19 BUMN). Sehingga dengan tugas tersebut membuat kinerja banyak BUMN bekerja tidak efisien. BUMN merupakan bentuk usaha negara yang sebagian atau keseluruhan modalnya milik negara atau pemerintah. BUMN sebagai public enterprise terdiri dua unsur, yakni unsur pemerintah dan bisnis (enterprise). Jadi BUMN tidak murni pemerintah dan tidak murni bisnis. Besaran persentase masing masing elemen disuatu BUMN tergantung jenis atau tipe BUMN-nya. Ada tiga makna yang terkandung dalam BUMN, yakni public purpose, public ownership dan public control. Dari ketiga makna itu public purpose-lah yang menjadi inti-konsep-BUMN. Public purpose ini mempunyai makna yang cukup luas. Karenanya BUMN-mempunyai tujuan ganda yakni sosial, politik dan ekonomi. (Anoraga, 2003)

Didalam mengukur kinerja keuangan suatu Badan Usaha/Perusahaan, ada terdapat beberapa alat ukur yang lazim digunakan, yaitu: Rasio Likuiditas, menunjukkan kemampuan memenuhi kewajiban keuangan jangka pendek tepat secara waktunya. Pengukuran dari rasio ini dapat menggunakan Current Ratio, Cash Ratio dan Acid Test Ratio. Current Ratio, merupakan rasio yang mengukur kemampuan memenuhi hutang jangka pendek dengan menggunakan aktiva lancar. Cash Ratio, merupakan kemampuan untuk membayar hutang yang jatuh tempo dengan kas yang ada atau surat berharga efek yang dapat segera diuangkan. Acid test Ratio, merupakan kemampuan untuk membayar hutang yang segera harus dipenuhi dengan aktiva lancar yang lebih likuid.

Rasio Profitabilitas, menunjukkan seberapa besar kemampuan-perusahaan-memperoleh laba, baik dalam hubungannya dengan penjualan, asset maupun laba bagi modal sendiri. Pengukuran dari rasio ini dapat menggunakan, Gross Profit Margin (GPM), Return On Assets (ROA), Return On Equity (ROE) dan Net Profit Margin (NPM). Gross Profit Margin (GPM), merupakan rasio atau pertimbangan antara laba kotor yang diperoleh perusahaan pada tingkat penjualan. Peneliti memilih rasio ini karena untuk mengetahui seberapa efektif pengelolaan biaya-biaya operasional perusahaan dalam kontribusinya terhadap penjualan. Return On Asset (ROA), merupakan rasio yang mengukur kemampuan perusahaan dari modal yang diinvestasikan untuk menghasilkan keuntungan bersih. Return On Equity, merupakan rasio untuk mengukurkemampuan dari modal-sendiri untuk menghasilkan-keuntungan bagi pemegang sahamnya. Net Profit Margin, merupakan keuntungan-bersih-per-rupiah penjualan.

Rasio Leverage, menunjukkan kemampuan untuk memenuhi kewajiban jangka pendek maupun kewajiban jangka panjang. Debt Ratio, rasio ini digunakan untuk mengukur presentase total dana dari-kreditur untuk membelanjai total aktiva. Debt to Equity Ratio, merupakan rasio untuk mengukur kinerja perusahaan berdasarkan hutang perusahaan dihitung dengan membagikan antara total hutang dengan total equity perusahaan yang digunakan sebagai sumber pendanaan usaha. Peneliti memilih rasio ini sebagai pengukuran kinerja keuangan, karena untuk mengetahui tingkat hutang perusahaan dan merupakan bagian dari rasio leverage. Long Term Debt Ratio, merupakan rasio yang mengukur kinerja perusahaan berdasarkan pada modal sendiri yang dijadikan jaminan untuk hutang jangka panjang.

Hubungan antara Manajemen Risiko dengan pencapaian tujuan organisasi/kinerja 
keuangan ditulis oleh beberapa peneliti. Temuan penelitian Li (2018) dalam jurnal; $A$ Study on Enterprise-Risk-Management and Business-Performance; menunjukan bahwa ada bukti yang cukup memadai yang menunjukkan Enterprise Risk Management berpengaruh terhadap Kinerja Usaha. Hasil empiris temuan penelitian Li (2016) dalam jurnal; Board Advising, Risk Taking, and Firm Performance; menunjukkan persentase direktur penasehat secara positif terkait dengan tingkat pengambilan risiko perusahaan, dan interaksi persentase direktur penasehat dan pengambilan risiko adalah berkorelasi positif dengan kinerja perusahaan di masa depan. Namun, efek ini tidak signifikan sama sekali di perusahaan milik negara karena campur tangan pemerintah.

Hubungan antara Internal Control dengan pencapaian tujuan organisasi/kinerja keuangan dilakukan oleh Kinyua, et al. (2015). Hasil riset menyimpulkan bahwa ada hubungan yang signifikan aantara lingkungan pengendalian internal dan kinerja keuangan, merekomendasikan agar lingkungan pengendalian internal harus ditingkatkan lebih jauh untuk meningkatkan kinerja keuangan perusahaan di Nairobi Securities Exchange. Temuan Basodan, (2015), mengungkapkan semua dimensi kontrol internal termasuk lingkungan kontrol, penilaian risiko, control prosedur, informasi dan komunikasi dan pemantauan memiliki hubungan positif dengan ukuran profitabilitas termasuk EPS, ROA, ROE dan PM. Namun, pengujian hipotesis menunjukkan bahwa ada beberapa perbedaan dalam signifikansi hubungan antara kontrol internal dan ukuran profitabilitas dan dalam hubungan antara komponen kontrol internal dengan berbagai ukuran profitabilitas.

Tettamanzi (2015) menemukan hubungan antara kepemilikan dan struktur tata kelola perusahaan dan kinerja perusahaan bersifat ambigu. Hasil penelitian Salamantun, (2015) menunjukkan bahwa penerapan GCG tidak berdampak pada kinerja perusahaanndengan ukuran EVA. Hasil penelitian Mayang Mahrani, Noorlailie Soewarno, (2018) dalam jurnal;"The effect of good corporate governance mechanism and corporate social responsibility on financial performance with earnings management as mediating variable", menunjukkan bahwa mekanisme GCG dan
CSR memiliki efek positif pada keuangan kinerja serta CSR pada kinerja keuangan.

Coetzee, (2016) menyimpukan bahwa kontribusi fungsi Audit Internal terhadap kegiatan manajemen risiko agak lemah. Temuan penelitian Zwaan, Stewart dan Subramaniam (2009) menunjukkan bahwa keterlibatan yang tinggi dalam ERM berdampak pada kesediaan auditor internal untuk melaporkan gangguan dalam prosedur risiko kepada komite audit. Auditor internal terlibat dalam kegiatan pemeriksaan ERM tetapi beberapa juga terlibat kegiatan yang dapat membahayakan objektivitas.

Hubungan Maturity Level / kualitas Audit Internal terhadap Internal Control ditulis oleh Mazza and Azzali (2015) adalah kompetensi dan independensi auditor internal mengurangi kelemahan kontrol internal. Sementara Zou (2019) menemukan bahwa audit internal memainkan peran yang tidak tergantikan dalam tata kelola perusahaan. Smith (2018) menunjukkan bahwa kinerja tinggi internal audit dikaitkanndengannukuran banyaknya rekomendasi untuk meningkatkan tata kelola perusahaan. Rahmatika (2014) menunjukkan bahwa fungsi intern audit memiliki efek positif pada kualitas pelaporan keuangan. Fungsi audit internal memiliki pengaruh positif pada Tatakelola yang baik. MartinovBennie, (2015) menemukan tingkat keterlibatan Internal Audit Function (IAF) yang sangat tinggi dalam masalah tata kelola, persepsi bahwa masalah tata kelola adalah yang paling penting saat ini bagi IAF, dan juga responden menilai tinggi keterampilan dan kompetensi IAF dalam hal kemampuan untuk melakukan penugasan yang berkaitan dengan masalah tata kelola. Suyono dan Hariyanto (2012) membuktikan bahwa pengendalian internal, audit internal, dan komitmen organisasi memiliki hubungan signifikan positif dengan tata kelola yang baik.

\section{Kesimpulan}

Artikel ini merupakan konsep hubungan antara managemen risiko, pengendalian internal, dan tata kelola terhadap kinerja keuangan, khususnya di ruang linkup BUMN. Auditor Internal sebagai alat Management dalam mengawasi jalannya proses bisnis perusahaan dalam usaha pencapaian tujuan 
perusahaan dirasa sangat penting, terutama sejak terjadinya sejumlah kasus keuangan dari beberapa perusahaan besar. Sesuai peraturan Pasar Modal dan Pemerintah (PP dan Undangundang BUMN), perusahaan BUMN di Indonesia diwajibkan untuk memiliki Departemen Audit Internal. Keberagamanan ukuran dan tingkat kemapanan (besar organisasi dan keahlian) dari Departemen Audit Internal di BUMN menimbulkan pertanyaan mendasar terkait keandalannya. Sertifikasi Maturity Level dari Departemen Audit Internal dipandang sebagai solusi untuk meyakinkan tingkat keandalan Auditor Internal didalam mensukseskan pencapaian tujuan perusahaan yang salah satunya diukur dengan kinerja keuangan. Tulisan ini ingin menguraikan dan memberikan ide penelitian hubungan Maturity Level Departemen Audit Internal dengan alat management perusahaan yang terdiri dari Pengawasan Internal, Managemen Risiko dan Tatakelola yang ada di Perusahaan dalam rangka peningkatan Kinerja Keuangan Perusahaan BUMN.

Berdasarkan pemikiran konseptual dan kajian hasil-hasi penelitian sebelumnya sangat dimungkinkan untuk dilakukan penelitian terkait dengan hubungan antara managemen risiko, pengendalian internal, dan tata kelola terhadap kinerja keuangan. Maturiy level departemen audit nternal dapat dibuktikan juga melalui riset sebagai pemoderasi hubungan antara managemen risiko, pengendalian internal, dan tata kelola terhadap kinerja keuangan. Riset lanjutan diharapkan dapat membuktikan secara empirir terkait dengan hubungan tersebut.

\section{Daftar Pustaka}

Adedokun, S. A. (2014). Internal Audit Function and Good Governance in Oyo State. Unpublished M. Sc. Accounting Dissertation). Obafemi Awolowo University, Ile-Ife, Nigeria.

Al-Thuneibat, A. A., Al-Rehaily, A. S., \& Basodan, Y. A. (2015). The impact of internal control requirements on profitability of Saudi shareholding companies. International Journal of Commerce and Management, 25(2), 196217.
Barasa, K. S. (2015). Statistical analysis of the role of internal audit in promoting good governance in public institutions in Kenya. Journal of Investment and Management, 4(1), 38-46.

Soh, D. S., \& Martinov-Bennie, N. (2015). Internal auditors' perceptions of their role in environmental, social and governance assurance and consulting. Managerial Auditing Journal, 30(1), 80-111.

De Andreis, F., \& Florio, M. (2019). Risk Management Instruments, Strategies and Impacts in the Complex Organizations. American Journal of Industrial and Business Management, 9(5), 1157-1167.

Fratini, F., \& Tettamanzi, P. (2015). Corporate governance and performance: Evidence from Italian companies. Open journal of business and management.

Institute of Internal Auditors - IIA. (2006). The Role of

Auditing in Public Sector Governance. Altamonte Springs, FL: The Institute of Internal Auditors Research Foundation.

Institute of Internal Auditors - IIA. (2008). International Standards for the Professional Practice of Internal,Auditing. Altamonte Springs, FL: The Institute of Internal Auditors Research Foundation

Institute of Internal Auditors - IIA. (2010). Internal Audit Process Maturity Altamonte Springs, FL: The Institute of Internal Auditors Research Foundation.

Institute of Internal Auditors - IIA. (2010). Measuring Internal Audit Effectiveness and Efficiency. IPPF- Practice guide. The Institute of Internal Auditors Research Foundation.

Kinyua, J. K., Gakure, R., Gekara, M., \& Orwa, G. (2015). Effect of internal control environment on the financial performance of companies quoted in the Nairobi Securities Exchange. International Journal of Innovative Finance and Economics Research, 3(4), 29-48.

Li, J. (2016). Board Advising, Risk-Taking, and Firm Performance. Journal of Financial Risk Management, 5(03), 149- 
160. http://dx.doi.org/10.4236/jfrm.2016.53015.

Li, L. (2018). A Study on Enterprise Risk Management and Business Performance. Journal of Financial Risk Management, 7(01), 123-138. https://doi.org/10.4236/jfrm.2018.71008.

Monday, J. U., Inneh, G. H., \&amp; Ojo, V. O. (2014). Effect of Internal Controls on Operating Performance of Small Business in Lagos Metropolis. Proceedings of the International Conference on Accounting, Finance and Management, 2, 237-256.

Maria Inez Sanchia, Tuntun Salamantun, (2015), Impact of Good Corporate Governance in Corporate Performance. International Journal of Management and Applied Science, Volume-1, Issue-9, Oct.2015, ISSN: 2394-7926.

Mahrani, M., \& Soewarno, N. (2018). The effect of good corporate governance mechanism and corporate social responsibility on financial performance with earnings management as mediating variable. Asian Journal of Accounting Research, 3(1), 41-60.

Coetzee, P. (2016). Contribution of internal auditing to risk management: Perceptions of public sector senior management. International Journal of Public Sector Management, 29(4), 348364.

Rahmatika, D. N. (2014). The impact of internal audit function effectiveness on quality of financial reporting and its implications on good government governance research on local government Indonesia. Research Journal of Finance and Accounting, 5(18), 64-75.

Abdullah, R., Ismail, Z., \& Smith, M. (2018). Audit committees' involvement and the effects of quality in the internal audit function on corporate governance. International Journal of Auditing, 22(3), 385-403.

Suyono, E., \& Hariyanto, E. (2012). Relationship between internal control, internal audit, and organization commitment with good governance: Indonesian case. China-USA Business Review, 11(9).

Spira, L. F., \& Page, M. (2003). Risk management: The reinvention of internal control and the changing role of internal audit. Accounting, Auditing \& Accountability Journal, 16(4), 640-661.

Mazza, T., \& Azzali, S. (2015). Effects of internal audit quality on the severity and persistence of controls deficiencies. International Journal of Auditing, 19(3), 148-165.

Zou, J. (2019). On the Role of Internal Audit in Corporate Governance. American Journal of Industrial and Business Management, 9(01), 63-71. https://doi.org/10.4236/ajibm.2019.91005.

UU No. 19/2003 tentang BUMN.

PP No. 45/2005 tentang Pendirian, Pengurusan, Pengawasan dan Pembubaran BUMN. 